\title{
Tourism Versus Sustainable Development Goals (SDG) Tourism - an Element of Economic Growth of Metropolitan Cities, Entrepreneurs
}

\author{
ZAKIYA SALIM ALHASNI \\ WARSAW SCHOOL OF ECONOMICS, COLLEGIUM OF WORLD ECONOMY, WARSAW, POLAND, \\ E-mail: za65806@doktorant.sgh.waw.pl
}

\begin{abstract}
Oman's economy highly depends on oil revenue since it accounts for more than half of all its export incomes. Other sectors like fishery and agriculture are some of other major sources of income that are perceived to have some influence on minimizing the economic gaps of the population while contributing constructively to the country's GDP. Oman being strategically and geographically located; tourism is thus viewed as a major contributor to the economy and its sustainability. The reason behind this is the fact that Oman possesses great tourism potential in terms of its culture, climate, and natural environment. This research elucidated the constructive economic effects of tourism in Oman that can generate revenues and maintain sustainable economic growth, which in turn can help the country achieve its SDGs.
\end{abstract}

Keywords: Sustainable tourism, SDGs, tourism, and SDGs, tourism in Oman

JEL Classification: L83, Z30, Z32 


\section{Introduction}

Sustainable tourism is a hotly contested aspect of economic development that is common in the contemporary world, compounded by the ongoing concerns of global climate change and other human influences. Sustainable development, in retrospect, is about conducting businesses appropriately and taking full account of the current and future economic implication of the various activities undertaken. From the tourism perspective, sustainability is about minimizing negative effects on the environment and local culture, while at the same time boosting the economic livelihood of the local communities in the region around the tourist destination (Causevic \& Neal, 2019). It is worth noting that the pursuit of sustainable tourism is an incessant process and needs continuous monitoring of impacts as well as reviewing and implementing appropriate strategic measures that supports the goal.

The United Nations 2030 Agenda is hinged on Sustainable Development, which embraces various economic, social, and environmental issues, challenges, and problems across different areas of human activity. For instance, the aims of SDGs are to achieve food security, to promote of lifelong learning for all, to promote sustainable economic growth, and to increase access to clean energy, among others. Thus, the UN called on businesses to take a leading role in ensuring the success of SDGs. Tourism is one of the fastest-growing industries around the world, which is expected to greatly contribute to the achievement of SDGs. As an illustration, Oman's National Centre of Statistics, and Information (NSCl) reported that the country experienced an increase in the number of tourists from under 1,400,000 in 2011 to over 3,200,000 in 2017 and tourism will account for about US\$ 8.67 billion of Oman's GDP by 2028. Thus, the objective of this paper is to examine the role of tourism in Oman and how it can lead to the achievement of its SDGs.

\section{Literature Review}

\subsection{The Concept of Sustainable Tourism}

The growing interest in sustainable development in the $21^{\text {st }}$ century is driving the need for improvement of every sector of economy across the globe. Tourism and hospitality industry one of such economic pillars that have drawn keen attention of researchers, academicians, and professionals who strive to investigate the emerging challenges and innovate sound solutions to promote sustainability. Although there is a broad conceptual framework relating to this subject, Ninerola, Sanchez-Rebull \& Hernandez-Lara (2019) emphasize that the most widely recognized assertion is that sustainable development in any given field is one that sufficiently meets the present needs without compromising or limiting the future generations. This implication cuts across the social, economic, and environmental dimension of the society.

It is needful to have a quick review of each of the three facets of sustainability, identified in the preceding paragraph, for better understanding of its relevance in the tourism sector. Economic sustainability goal seeks to achieve efficient utilization of the available scarce resources and generate profits out of them, both in the short-run and long-run. In the case of social sustainability, the primary focus is on aspects such as social justice, moral social responsibility, caring for human capital and community development (Ninerola, Sanchez-Rebull \& Hernandez-Lara, 2019). Fulfilment of sustainable social welfare occurs when diverse communities stay equitable, united, democratic, and enjoy a healthy living standard.

Last, the need for environmental sustainability requires that the available natural resources are conserved, maintained, and used judiciously, so that they can last long. Proper caring for the surrounding simply means safeguarding the usefulness of natural assets on the earth's surface, protecting them from pollution, depletion, and extinction (in the case of wildlife). The pursuit of all these pillars must occur simultaneously for they have critical role in the overall well-being of human civilization over time. Failure to meet one would render the impact of the remaining two almost insignificant. So, sustainability in the lens of tourism is mainly about minimizing negative effects on the 
environment and local culture, while at the same time boosting the economic livelihood of the local communities in the region around the tourist destination (Streimikiene et al., 2020).

Tourism is recognized as one of the fastest growing and rapidly transforming sectors in the world. Besides, it is also among the most fragile and vulnerable fields in relation to social problems like political instabilities and pandemics. In its 2020 report, for example, the World Travel and Tourism Council reveals that the industry experienced the global travel and tourism sector recorded $3.9 \%$ growth. This statistic translated into the eighth consecutive time where the industry growth outpaced the growth rate of the overall economy by nearly 3.2\% (Streimikiene et al., 2020). Other revelations also show that that the industry has been able to create about one-fifth of the new jobs in various countries over the past 5 years. This amazing potential is a metric of prosperity for governments; hence it requires regular monitoring and maintenance to ensure constant growth.

\subsubsection{Impacts of Covid-19 on the Tourism Sector}

As already highlight in the previous section, tourism sector is a highly sensitive to social-related challenges. Matters pertaining to political climates and community health must are the major factors that influence the attractiveness of a location. Political instability and high health risk levels can thwart the performance of the industry completely. The case of Covid-19 that paralyzed the entire global economy in 2020 is a clear evidence of how the situation can look like. Tourism and Travel Industry have been the worst hit areas that literally remained sabotaged for a long time. According to the most recent update by the United Nations World Trade Organization (UNWTD), travel and tourism sector is the most affected economic area with a massive decline in the international demand following the worldwide restrictions imposed to contain the virus. The report clarifies that the statistics of the international tourist arrivals exhibited a $70 \%$ drop in the period January-August 2020 compared to a similar period in the previous year (UNWTD, 2020). Such a sharp decline is attributed to the travel restrictions, along with the complete closure of many borders by various jurisdictions. From a financial perspective, this fall in tourist travel translates into an estimated loss of US\$730 billion in export revenues that accrues from international tourism (UNWTD, 2020)

The impacts of pandemic cited above is quite relevant to the subject of sustainable tourism as it has revealed how inadequate risk preparedness by governments and other stakeholders can mess the industry. Lack of proactive risk mitigation measures and other poor corporate practices of many have mad many firms to incur massive losses; some even file for bankruptcy and eventually shut down. The ultimate impacts of the pandemic in the sector include decline in international travel, suspension of flights, reduced profitability, and forceful dismissal of workers. To overcome or withstand such challenges in the future, more studies and implementation of sustainable measures are essential across all economic sectors especial tourism. Therefore, an empirical study of Omani tourism sector in reference to SDGs is a positive step in the right direction.

\subsection{Tourism in Oman}

Oman is a Middle East country located right in the eastern parts of the Arabian Peninsula. The country experiences a range of climatic patterns - hot and humid condition along the coastal shores, mild coldness in the mountain regions, and monsoon around the southern regions. Hafidh et al. (2020) emphasize that four UNESCO World Heritage sites are among the fascinating tourist hotspots in the area. These economic features include but not limited to the Alfaj Traditional Irrigation System; the 5000-years-old Bat Tombs; Ballah Fort; and Land of Frankincence (Causevic \& Neal, 2019). These scenaries place Oman in a favorable position to attract a substantial volume of tourist niche markets as types of ecotourism such as cultural tourism, adventure tourism, bird watching, desert tourism, and geo-tourism. Even so, it is reported that the Omani government is underutilizing its rich ecotourism portfolio (Hafidh et al., 2017). Formulation and implementation of green tourism practice would help the country achieve sustainable development, rather than prioritizing the petroleum deposits. 
The diversification of the economy by the government has had a significant positive impact on tourism. Saxena (2002) argues that like other oil-producing nations, Oman's economy greatly depends on oil and gas. However, the country supplements its economy through other sectors, particularly tourism since overdependence on only one sector is risky for the country. According to Omari (2019), political stability is a major factor that has contributed to the growth of tourism in Oman. Moreover, economic insecurity and fluctuations in the oil market have also considerably contributed to the success of the tourism sector (Callen, et al., 2014). The oil and gas industry are volatile and susceptible to external forces. Countries that rely on oil face unreliable future in their economy if they only rely on oil and gas for revenue. Therefore, their governments have enforced policies that focused on promoting diversification of the economy through tourism to minimize overdependence on oil solely (Hvidt, 2013, Hertog, 2013, Cherif \& Hasanov, 2014; Khan and Qureshi 2020)).

\section{Methodology/Materials}

The study involved an analysis of several articles on sustainable tourism published between 2010 and 2018. The researcher used content analysis to conduct bibliometric as well as thematic analyses. The researcher chose articles from the Journal of Sustainable Tourism (JST) since it is a reputable tourism journal. Also, the study used full-length research articles only since they give comprehensive information about the theoretical concepts or frameworks, research methods, and managerial guidance (Nunkoo, Smith \& Ramkissoon, 2013). The selected articles were analyzed using content analysis to guarantee their completeness and quality (Fong, Law, Tang, \& Yap, 2016; Mohammed, Guillet \& Law, 2015; Xiao \& Smith, 2006). The study used two scient metric programs namely, Cite Space and VOS viewer to help in visualizing the results. The analyzed aspects of the selected articles include impact analysis, collaboration analysis, thematic coverage, and collaboration analysis since they were deemed sufficient to the study's research question.

In total, the study utilized 20 source materials, most of which were scholarly peer reviewed journal articles based on sustainability and tourism sector across the world. These sources have been strategically selected and evaluated in the sense that the publication date of the majority (over $70 \%$ ) is below 10 years, and the context of their coverage perfectly matches the Omani tourism and hospitality sector. Content analysis is undertaken to help in the identification of categories and generation of precise qualitative information of the previous literature works. The criteria of sorting were in the following format (1) subject area; (2) publication journal/databases (3) region of focus; (4) year of publication; and number of references (5). All these steps were observed with the goal of aligning data analysis with the context of tourism in Oman.

\section{Results}

There is a considerable volume of evidence that Omani government exhibits tremendous commitment to the pursuit of sustainable tourism. The country's ministry in charge of tourism has been on the record of publishing guidebooks concerning promotional information about Oman's rich tourist destinations. Such a marketing move is beneficial as many readers are able to find out the interesting features about the environment, ecology, culture, and heritage of the country. This technique has the potential of drawing significant influx of tourist population to the country, especially scholars, academicians, and professionals in the field for purposes of research. Despite the widely appreciated effort of publications done by the Ministry of Tourism, some studies have pointed to the issue of inadequate on-site information that tourists find as a challenge as their guides have been unable to give satisfactory interpretation in specific aspects. For example, prominent scenaries like the Tower Tombs of Wadi Al Ain does not have signage nor interpretation (Tewari, 2019). This is a mistake that the government must note and address to avoid dissatisfaction among visitors and bad reputation.

Regarding the focus on economic and social-based sustainability, Omani government has shown the interest of engaging members of the public through measures like promotion of domestic tourism, education, and employment opportunities. However, the positive impacts of these undertakings have 
not taken shape in the living standards of village residents (Mishra \& Jain, 2020). The feasible economic benefits of tourist activities are still absent among the rural dwellers as most of them still wallow in abject poverty. Positive improvement of the sector should translate into a corresponding transformation of the living standard of the citizens across the board. Thus, the government need to leverage more efforts in its quest for sustainability of the tourism sector.

\section{Finding}

Tourism has greater economic benefits to the citizens of Oman since its expansion will improve the quality of life and will help its people acquire novel skills, knowledge and capabilities, employment, and development of businesses across the nation (Liu \& Wall, 2006). The opportunities that come due to tourism can not be ignored. Many people can expand their businesses through investment in hotels and accommodation to take advantage of the visitors getting into the country. Furthermore, the country is able to preserve its values and cultural assets and consolidate its domestic pride and its citizen's identity (Henderson, 2015). Besides, tourism will also help Oman to achieve its SDGs. The nation is also bound to improve services like education and transport making sure that the country attracts more tourists. This in turn helps the natives to better their lives.

\section{Discussions}

Tourism has greater economic benefits to the citizens of Oman since its expansion will improve the quality of life and will help its people acquire novel skills, knowledge and capabilities, employment, and development of businesses across the nation (Liu \& Wall, 2006). Also, the country will preserve its values and cultural assets and consolidate its domestic pride and its citizen's identity (Henderson, 2015). In addition, tourism will also help Oman to achieve its SDGs.

\section{Conclusion}

Although tourism plays a great role in the generation of revenues needed to maintain a sustainable economy, actionable and enforceable policies must be initiated to improve the tourism sector in Oman. Moreover, Oman's higher learning institutions should initiate professional courses that will boost the tourism industry in the country. Tourism has a huge potential in Oman and its development can cushion the country against shocks in the oil industry, thereby helping the country to achieve it SDGs on time.

\subsection{Limitations and Future Studies}

This work was subject to the constraints of parameters such as time, financial resources, and source materials. The duration of its compilation was limited hence some areas pertaining to sustainable tourism and SDGs have not be exhausted. Regarding the source materials, the study primarily depended on secondary data; the ongoing concerns over Covid19 led to restrictions of movement that made it impossible to collect first-hand information from the sites. Some secondary reports could be biases. Based on the data analysis and results obtained, further studies should focus on the novel innovative concepts of sustainable tourism and how the Omani government an utilize them to improve its industry. Potential examples of such concepts include film tourism and trails.

\section{Acknowledgement}

I am very proud to have written part of my PhD requirements, which is writing articles for a journal, it was a very challenging experience that went through every page with in-depth research and reviews. Moreover, the quality of this work is due to the most important contributions from various people to whom I have been helped to complete the hard work and share some good ideas, to whom I owe a lot of gratitude and appreciation. I would like to thank all my generous family, especially my dear mother who has a role in my life. For their tremendous support by providing a conducive work environment 
for me to complete this task to the level I have reached. Many of my family, friends, co-workers, and anyone else support this process either directly or indirectly.

\section{References}

1. Buerkert, A., Luedeling, E., Dickhoefer, U., Lohrer, K., Mershen, B., \& Schaeper, W. et al. (2010). Prospects of mountain ecotourism in Oman: the example of As Sawjarah on Al Jabal al Akhdar. Journal of Ecotourism, 9(2), 104-116. https://doi.org/10.1080/14724040902803404

2. Callen, M. T., Cherif, R., Hasanov, F., Hegazy, M. A., \& Khandelwal, P. (2014). Economic diversification in the GCC: Past, present, and future, International Monetary Fund.

3. Causevic, S., \& Neal, M. (2019). The exotic veil: Managing tourist perceptions of national history and statehood in Oman. Tourism Management, 71, 504-517. https://doi.org/10.1016/j.tourman.2018.10.001

4. Cherif, R., \& Hasanov, F. (2014). Soaring of the gulf falcons: Diversification in the GCC oil exporters in seven propositions (No. 14-177), International Monetary Fund.

5. Fong, L. H. N., Law, R., Tang, C. M. F., \& Yap, M. H. T. (2016). Experimental research in hospitality and tourism: a critical review, International Journal of Contemporary Hospitality Management, 28, 2, 246-266.

6. Hafidh, A., Noel, S., Ahmad, M., \& Jafar, J. (2017). Evaluating ecotourism challenges in Oman. International Tourism Development And The Gulf Cooperation Council States, 156-168. https://doi.org/10.4324/9781315776576-10

7. Henderson, J. C. (2015). The development of tourist destinations in the Gulf: Oman and Qatar compared, Tourism Planning \& Development, 12(3), 350-361.

8. Hvidt, M. (2013). Economic diversification in GCC countries: Past record and future trends. London, UK: London School of Economics.

9. Hertog, S. (2013). The private sector and reform in the Gulf Cooperation Council, London,UK:LSE Kuwait Programme.

10.Literature: A content analysis of hospitality and tourism journals, International Journal of Hospitality Management, 44, 99-110.

11.Liu, A., \& Wall, G. (2006). Planning tourism employment: a developing country perspective, Tourism Management, 27(1), 159-170.

12.Mishra, A., \& Jain, V. (2020). Residents Perceptions Toward Tourism as a Community Development Tool: A Case of Sultanate of Oman. Journal Of Tourism And Gastronomy Studies, 8(4), 478-489. https://doi.org/10.21325/jotags.2020.699

13.Mohammed, I., Guillet, B. D., \& Law, R. (2015). The contributions of economics to hospitality

14.Niñerola, A., Sánchez-Rebull, M., \& Hernández-Lara, A. (2019). Tourism Research on Sustainability: A Bibliometric Analysis. Sustainability, 11(5), 1377. https://doi.org/10.3390/su11051377

15.Streimikiene, D., Svagzdiene, B., Jasinskas, E., \& Simanavicius, A. (2020). Sustainable tourism development and competitiveness: The systematic literature review. Sustainable Development. https://doi.org/10.1002/sd.2133

16.Tewari, V. (2019). Seasonality in Tourism: The Case of Oman. Ottoman Journal Of Tourism And Management Research, 4(2), 463-476. https://doi.org/10.26465/ojtmr.2018339522

17.Nunkoo, R., Smith, S. L., \& Ramkissoon, H. (2013). R esidents' attitudes to tourism: A longitudinal study of 140 articles from 1984 to 2010, Journal of Sustainable Tourism, 21(1), 5-25.

18.Omari, B. K. A. (2019). Tourism Economics in Oman: A statistical Study for The Period 2000 2017, Gsj, 7(3): 301-314.

19.UNWTO. (2020). Impact assessment of the COVID-19 outbreak on international tourism | UNWTO. Retrieved 2 December 2020, from https://www.unwto.org/impact-assessment-of-the-covid-19outbreak-on-international-tourism

20.Xiao, H., \& Smith, S. L. (2006). The making of tourism research: Insights from a social science journal, Annals of Tourism Research, 33(2), 490-507. 
Tourism Versus Sustainable Development Goals (SDG) Tourism - an Element of Economic Growth of Metropolitan Cities, Entrepreneurs

21.Khan, N., and M. I. Qureshi. 2020. "A Systematic Literature Review on Online Medical Services in Malaysia." International Journal of Online and Biomedical Engineering 16(6):107-18. 